This item was submitted to Loughborough's Research Repository by the author.

Items in Figshare are protected by copyright, with all rights reserved, unless otherwise indicated.

\title{
Trends in political television fiction in the UK: themes, characters and
} narratives, 1965-2009

PLEASE CITE THE PUBLISHED VERSION

http://dx.doi.org/10.1177/0163443711433663

PUBLISHER

Sage Publications Ltd / @ the authors

VERSION

SMUR (Submitted Manuscript Under Review)

LICENCE

CC BY-NC-ND 4.0

\section{REPOSITORY RECORD}

van Zoonen, Liesbet, and Dominic Wring. 2019. "Trends in Political Television Fiction in the UK: Themes, Characters and Narratives, 1965-2009”. figshare. https://hdl.handle.net/2134/13448. 
This item was submitted to Loughborough's Institutional Repository (https://dspace.lboro.ac.uk/) by the author and is made available under the following Creative Commons Licence conditions.

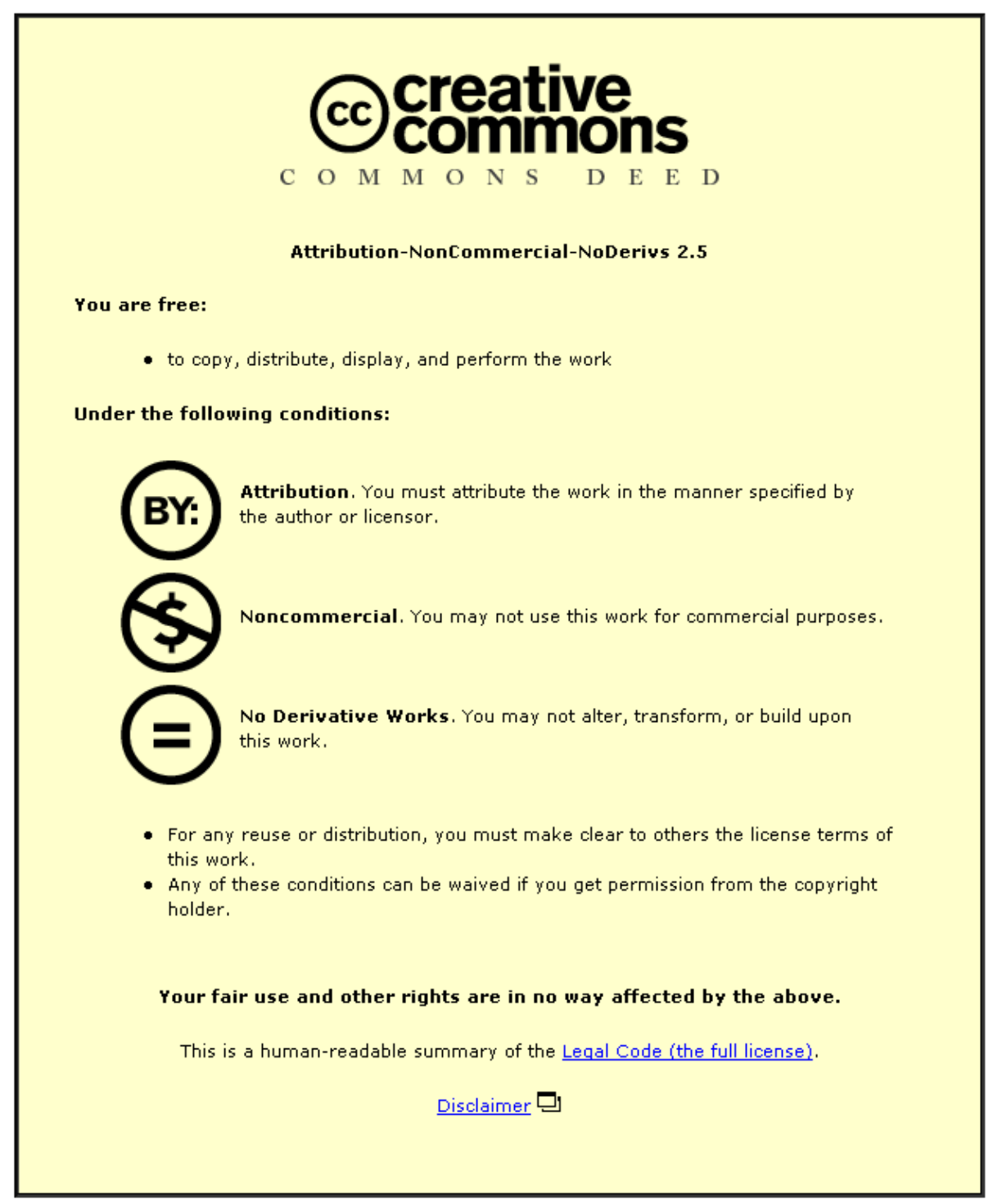

For the full text of this licence, please go to: http://creativecommons.org/licenses/by-nc-nd/2.5/ 
Trends in political television fiction in the UK:

Themes, characters and narratives, 1965-2009. 


\section{Introduction}

British television has a long tradition of broadcasting 'political fiction' if this is understood as telling stories about politicians in the form of drama, thrillers and comedies. Vote, Vote for Nigel Barton (1965) is generally considered the first of these productions for a mass audience presented in the then usual format of the single television play. Ever since there has been a regular stream of such TV series and TV-movies, varying in success and audience appeal, including massive hits and considerable failures. Television fiction has thus become one of the arenas of political imagination, together with literature, art and - to a lesser extent -music. Yet, while literature and the arts have regularly been discussed and analyzed as relevant to politics (e.g. Harvie, 1991; Horton and Baumeister, 1996), political television fiction in the UK has only recently become subject to academic scrutiny, leaving many questions as to its meanings and relevance still to be systematically addressed.

In this article we present an historical and generic analysis in order to produce a benchmark for this emerging field, and for comparison with other national traditions in political TV-fiction. We first elaborate the question why the study of the subject is important, what is already known about its themes, characters and narratives, and its capacity to evoke particular kinds of political engagement or disengagement. We then present our approach to our historical and generic comparison and give a brief overview of the material. We identify and discuss three genres in which UK political TV-fiction has been shaped throughout the decades: comedy, thriller and drama. We conclude with a discussion as to whether and how these trends and tendencies are likely to politically engage audiences.

\section{Political television fiction: character, theme and narrative.}

While fiction about political and electoral processes has been a visible and important element of British television, it has been little researched (but see for exceptions Corner and Richardson, 2007; Fielding, 2008). The situation is markedly different in the United States, where both topic related film and television fiction and their meanings for audiences have been analyzed at length. The West Wing, a seven season drama series about the US president and his staff, has, for instance, been exhaustively examined for its educational, inspirational and ideological values (e.g. Parry-Giles and Parry-Giles, 2006; Rollins and O'Connor, 2003), but also for the way it addresses and engages audiences as citizens. The series received criticism because of its overtly liberal politics and was derided as the entertainment industry's answer to the Bush government, but was also praised for the way it showed the presidency and public office as basically noble endeavors pursued by decent people often overwhelmed by the enormity of their challenges. The series has been articulated 
through the particular American variety of social realism associated with the populism inherent in Frank Capra's idealistic depictions of the power of individuals to take control of their lives and their government (O'Connor and Rollins, 2003, p. 13). It has also been said that amidst the hegemony of cynicism within American news reporting, The West Wing offered a way 'to overcome political malaise and feel connected to the presidency in ways that formal journalism cannot facilitate' (Pompper, 2003, p. 19).

Audience research about the interpretation of The West Wing supports this claim and has shown that regular viewers have a more positive understanding of the institution of the presidency, and of individual presidents, regardless of their political affiliation (Holbert et al., 2003). Van Zoonen (2007) has shown for many other examples of political film and television fiction (mostly from the US) how it enables audiences to learn about politics, reflect on it and judge it, and to imagine ideal political situations and practices. There thus seems to be enough empirical evidence to claim that political television fiction can function as a source of political imagination and understanding, complementing or even contrasting the standard sources that journalism offers. Note, in addition, that journalism itself also uses the narratives of popular culture to present their political news (cf. Van Zoonen, 2003; Tenenboim-Weinblatt, 2009), and that TV-makers themselves have always assumed the relevance of political fiction. For instance, acclaimed writer Dennis Potter, creator of Vote, Vote for Nigel Barton and numerous other television plays, said of the portrayal of class conflicts in the accompanying piece Stand up for Nigel Barton: 'I knew that in small family groupings - that is, at their most vulnerable - both coalminers and Oxford dons would probably see the play... In the theatre - or, at least, in the West End - the audience would have been largely only on one side of this particular fence. There is no other medium which could virtually guarantee an audience of millions with a full quota of manual workers and stockbrokers for a 'serious' play about class'. ${ }^{1}$ The subsequent question, then, is what are the resources that political television fiction offers, and of which they consist. Research in the field has focused mostly on two topics: the textual features of political television fiction in terms of characters, themes and narratives; and the particular engagement it invites from audiences.

Many authors have observed that much US political film and TV fiction takes the White House as the main setting and the president as main protagonist (Rollins and O'Connor, 2003). The generic codes and convention of film- and television drama require a focus on individual characters which focuses political fiction on stories of individuals or groups of individuals engaged in politics. Gianos (1998, p. 170), for instance, argues that his analysis of political Hollywood films suggests 'the nearly complete focus on the individual (...) to the virtual exclusion of other elements of political life,

1 Quoted on http://www.yorksj.ac.uk/potter/sunb.htm. 
is entirely consistent with the classical narrative style of movies, particularly U.S. movies'. Many titles thus refer to the main protagonists or their political function, as in Mr. Smith Goes to Washington, All the President's Men or Tanner, the eponymous character in a TV series about a would be Democratic presidential candidate that ran during the real party nomination process. Van Zoonen $(2005$, see also Haas, 2005) has added that these individuals are primarily men with women mostly cast as helpers to the main protagonist. The title of an British sitcom about a female MP is typical: No Job for a Lady.

While the focus on individual politicians is common to the genre, the themes in which these characters are caught up differ but are drawn within relatively tight boundaries. Giglio (2005) lists six dominant themes in Hollywood political fiction : political campaigns and conventions, political machines, capital crimes and misdemeanors, macho men, presidents and assassinations. He concludes that office holders are stereotyped in three roles as idealists, saviors and villains, with the villain role becoming ever more dominant. These themes are all easily connected to the personalized, character driven stories that typify popular film and television fiction. Issue driven portrayals of politics are much more rare, but have focused on war (e.g. Robb, 2004), nuclear and environmental disaster (e.g. Giglio, 2005). A common observation in these thematic inventories is that the themes of political film and television are tied up with the political concerns of the particular era in which they are made. Hollywood films about politics have particularly been approached as 'a cinematic canvas of the nation's history' (Krukones, 2003). Thus, many an author categorizes political film fiction by decade or period. Christensen and Haas (2005), for instance, connect the political films of the 1930s to the heightened social awareness in Hollywood resulting from the Depression; the 1940s and World War II obviously produced many war themes in political films, and the 1950s output was full of anti-communism but also contained critique of McCarthyism. The authors identify the 1960s as a period in which 'American filmmakers more willingly criticized the dominant values of their society' (p. 128) culminating in the movies of the Seventies that criticized the war in Vietnam. However according to Christensen and Haas the 1980s and 1990s saw a diversification of political films. Neve (1992) takes a similar approach in his analysis of the political content of American films that discusses them in historical order. He too identifies some recurring motifs: anti-intellectualism, the myth of a lost golden age of the simple life, reverence for the land and countryside, distrust of monied power and a belief in common sense biblical morality, often embodied in certain leaders (p. 33).

The combination of characters, themes and motives into a coherent and appealing film or television series can take on different generic and narrative forms. Holbert (2005) offers a typology of political entertainment which indicates some of the genres one can find in political TV fiction: situation comedy, fictional drama and docu-drama. Van Zoonen (2005) takes a different approach 
and does not identify genres but rather narratives that are often used in political fiction. A typical one that combines well with the individualized focus of popular film and television fictions is the quest in which an honest, virtuous candidate pursues his political ideals against the odds. The obvious example of this is the 1930s Hollywood classic Mr. Smith Goes to Washington and many other political films and TV-series have been told in this manner. The quest is often conducted in the context of another narrative, according to Van Zoonen (ibid), namely that of a conspiracy in which obscure and self-interested (groups of) individuals frustrate the democratic process. In the American TV series 24, for instance, terrorist schemes usually run all the way into the White House, where only a handful of officeholders can be trusted (not always including the president him or herself). While quest and conspiracy narratives both include clearly defined individual protagonists and antagonists, two other narratives are driven by collective processes often beyond the control of the individual. These too, have a dark and a light variety, with the former usually telling how the inexplicable workings of the system or 'machine' frustrate the ideals of individual politicians (the 'bureaucracy' narrative with the US comedy Spin City as an example)and the latter portraying a community of candidates and support staff in their everyday interactions, failures and victories. Such a 'soap' narrative is, for instance, evident in The West Wing.

We will use character, theme, and narrative as the analytic dimensions to compare the portrayal of politics and politicians in British television fiction. These three dimensions make it possible to identify developments through time (diachronically), but also to compare particular series with each other (synchronically). They also offer a more specific approach in the further exploration of the potentially engaging qualities of popular TV and film fiction about politics. Many authors have concluded that such fiction has by and large produced disengagement. Christensen and Haas (2005) believe their historical review of political messages in American film indicates that 'if audiences absorb these repeated messages, their cumulative effect must surely be cynicism and apathy' ( $p$. 278). Likewise, Giglio (2005) suggests that 'the present mood depicted in Hollywood films is a misrepresentation of the majority of decent, honest, hard-working people, elected and appointed, in government' (p. 144). Writing about nine political movies in the UK, Fielding (2008) argues that the films construct a clear oppositions between 'us', the ordinary citizens and audiences, and 'them', the self-obsessed politicians presenting a strong anti-party populism (p.126). Street (2002) has claimed that television comedies like Yes Minister and Yes Prime Minister contribute to feelings of cynicism and general anti-politics climate prevalent in UK culture. Conversely as discussed above, The West Wing has been praised for its engaging qualities, and likewise Corner and Richardson (2007) have argued that the British series The Amazing Mrs. Pritchard both encourages trust whilst demonstrating the limits of political action. Allied to this, popular film and television fiction are increasingly assumed to be an appropriate lens through which to better understand politics and 
'bring politics to life' (Foy, 2008, p.3). Part of the controversy is that the assertions about the (dis)engaging qualities of political film and television fiction are based on too general claims that try to cover all fiction over time periods, or - paradoxically - on to specific ones, expanding from individual series too overall processes. An intermediate level of analysis systematically comparing time periods and narratives is arguably lacking in the debate, although some authors have suggested that the quest and soap narrative offer specific possibilities for engagement, whereas conspiracy and bureaucracy are more likely to invite disengagement (Street, 2002; Neve, 2000; Van Zoonen, 2005).

\section{Method}

We define UK political television fiction narrowly as those programs or series that primarily tell stories about fictional politicians. This meant that plays or series in which politicians appear but not on central stage are excluded from our data. A contemporary example would be the BBC drama series Spooks about MI5. This also meant that historical representations of politics in, for instance, The Pallisers (1974) were also left out of the sample. We did not include movies about politics that were rereleased on TV. And the consequence was that, finally, we did not include the recent docudramas about, for instance, Margaret Thatcher, Tony Blair or the invasion in Iraq.

We compiled the body of material by first identifying relevant programs on the basis of our own individual recollections; the second step concerned consultation of the IMDB Movie Database to snowball from the first list, and to search it using key search terms like "political television drama" and variants of this; the same search terms were used for the online archives of the BFI (Screen Online) and for a general Google search; finally we presented the list to a number of colleagues for further suggestions ${ }^{2}$. The resulting titles are represented in the appendix: the list of these is extensive although not exhaustive and it contains TV productions of the kind Potter invoked when he spoke of attracting a large and diverse audience. On the basis of this compilation we made a first categorization of three genres in which UK political fiction has been framed: comedy, thriller and drama.

The next step in our procedure was to use the online sources to gather as much data as possible about characters, themes and narratives of the separate titles, producing the intertextual information that would help us analyze the selected titles. We used a bottom up method of constant comparison of each individual title to the next. Before we present the results of the generic analyses we give a brief overview of the material.

\footnotetext{
${ }^{2}$ At the Department of Social Sciences, Loughborough University; at the Media, Communication and Cultural Studies Association, London; at the Political Science Association, Edinburgh.
} 
Our inventory produced 33 distinct titles of television series and plays about politics, more or less evenly divided between comedy (13 titles), thriller ( 7 titles) , and drama (13 titles, see appendix). Despite the historical and contemporary presence of single plays, or made-for-television movies, the more common kind of political fiction concerns a number of series with weekly episodes. Drama and thrillers mostly ran for one season (with the exception of the House of Cards trilogy), whereas comedies usually went on for more than one season. In Figure 1 we represent how many episodes of drama, comedy and thrillers were made from 1965 till 2009.

Figure 1. UK television fiction episodes about politics, 1965-2009

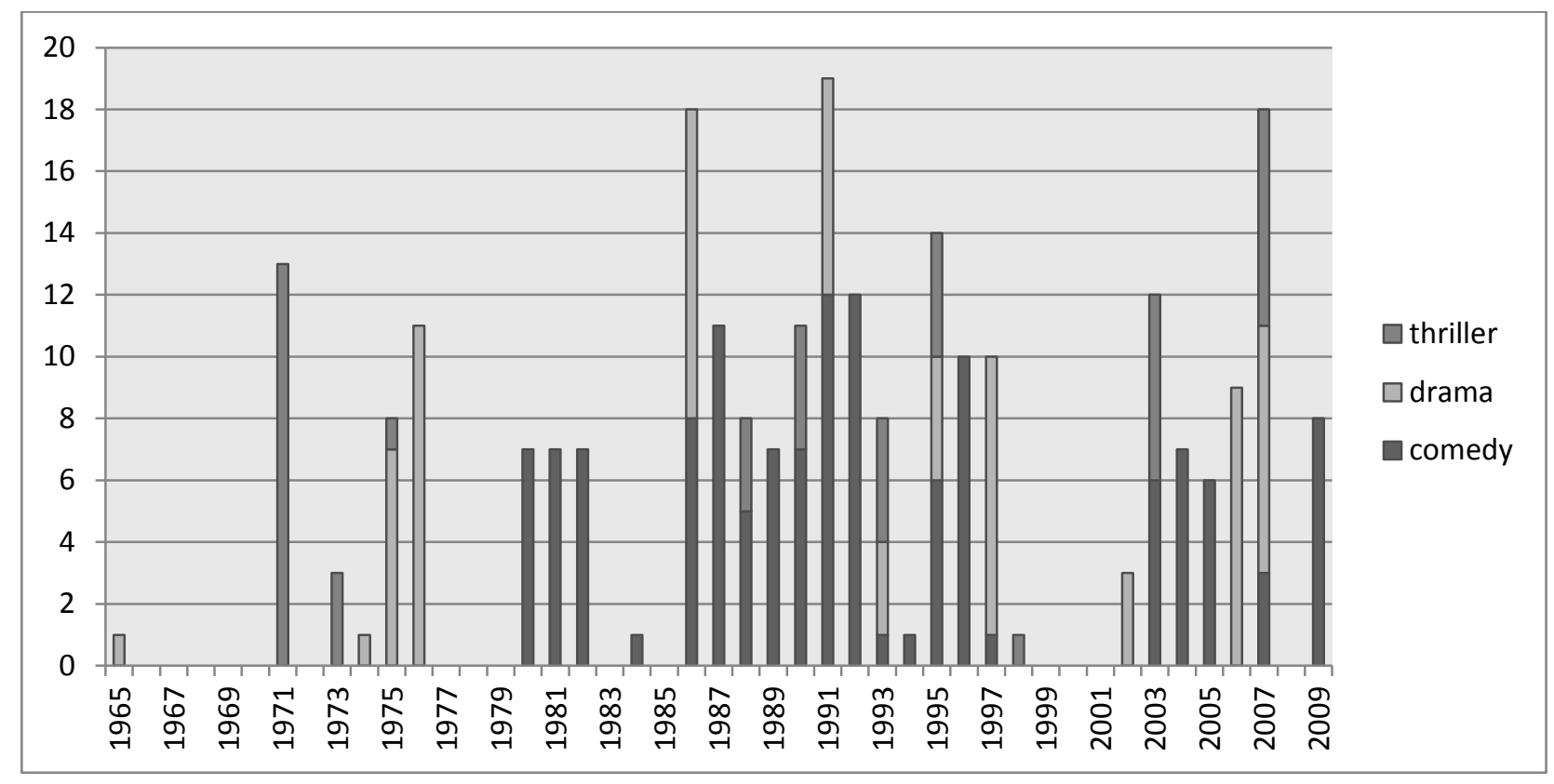

Figure 1 shows that political TV-fiction took off as a regular feature of British television in the early 1980ies with Yes Minister, and Yes Prime Minister and has been present in its diversity of genres ever since (with an exception around the millennium). The next sections discusses the characters, themes and narratives of these genres in more detail.

\section{Comedy}

Yes Minister and Yes Prime Minister are widely regarded as high quality British comedy, both by audiences and politicians alike. The latter group considered it the best political comedy ever when asked in $2006 .^{3}$ Its main protagonists minister Jim Hacker (played by Paul Eddington) and his leading

\footnotetext{
${ }^{3}$ http://www.manchestereveningnews.co.uk/entertainment/film and tv/s/230447 yes minister tops politica I comedy list, see for a poll among a general audience: http://www.bbc.co.uk/sitcom/winner.shtml, last accessed April 22, 2010.
} 
civil servant Sir Humphrey Appleby (Nigel Hawthorne) continuously bicker and struggle in plots that revolve around 'political games and clashes between politicians and the civil service that could be found almost everywhere in the world' as one fan sites puts it ${ }^{4}$. The BBC describes the series as embodying 'the early 1980s attitude to authority and politics as a gently hypocritical world filled with doubletalk'. ${ }^{5}$ The overarching story told in Yes (Prime) Minister is that of a political and bureaucratic machinery run by self-interested people. Furthermore the minister is not very bright and naive, whereas the civil servant is smart and scheming.

The theme of self-interest is more strongly present in The New Statesman, a comedy about a malevolent Conservative MP Alan B'Stard who is elected having caused the deaths of his opponents. B'stard is portrayed as greedy, narcissistic and sadistic in a series that has been described as Yes Minister meets The Young Ones given actor Rik Mayall stars in the former and latter, and also because of the absurdist and corporeal features of the programme. ${ }^{6}$ One running joke has the MP routinely administering punishment to his dim witted parliamentary colleague, the hapless Piers, who himself is a caricature of the more traditional Conservative politician. Other MPs are invariably represented as foolish, opportunistic or feeble. A similar kind of humor informs the most recent high profile British production The Thick of $I t$, a programme described as 'dark political comedy set in the corridors of British government' by the $\mathrm{BBC}^{7}$, and as a modern day Yes Minister with 'much, much more swearing'. ${ }^{8}$ Its main source of humor are the conflicts between the ineffectual minister of the Department of Social Affairs and Citizenship, and the rude foul-mouthed Downing Street's chief spin doctor Malcolm Tucker played by Peter Capaldi, who routinely responds to a knock on the door with obscenities such as 'Come the fuck in or fuck the fuck off'. ${ }^{9}$ It is interesting that a brief series of ten minute satirical sketches, Look at the State We're In, featuring Mayall, John Cleese, Imelda Staunton and Hugh Laurie was made for BBC2 in 1995 as part of a package of programmes about citizen rights and took a similar approach to the aforementioned comedies. Cynical comments by civil servants abound in these attempts to address the public about such diverse topics as quangos, VAT regulation and information laws:

'We don't have to behave like unscrupulous, sadistic, megalomaniacs, the system does that for us'. [Episode 1, the Organisation]

4 http://www.yes-minister.com/introduc.htm, last accessed April 22, 2010.

5 http://www.bbc.co.uk/comedy/yesminister/index.shtml, last accessed April 22, 2010.

6 Rick Mayall played one of the four leading characters in The Young Ones, a British cult comedy of the early 1980s.

7 http://www.bbc.co.uk/programmes/b006qgrd, last accessed April 22, 2010.

$8 \mathrm{http} / /$ www.comedy.co.uk/guide/tv/the thick of it/, last accessed April 22, 2010.

9 http://www.guardian.co.uk/tv-and-radio/tvandradioblog/2009/oct/15/thick-of-it-malcolm-tucker, accessed April 22, 2010. 
'These guidelines are voluntary. We are obliged to help you, but only if we fee like it' [Episode 2, Secrecy].

It appears that British political sitcoms thrive on portraying politicians and civil servants as dimwitted, lazy and unco-operative at best, and as malign, manipulative and obsessed at worst. Commonly these dramas are set in a bureaucratic environment where characters are governed by incomprehensible codes and conventions that are resistant to change, in the unlikely event that a protagonist would be interested in pursuing such an agenda. Failure and derision are their inevitable fate. There are few exceptions to this trend, the most notable one being the little remembered, less frenetic sitcom No Job for a Lady, in which Penelope Keith portrays a socially conscientious Labour MP whose down to earth common sense in the tested by incomprehensible parliamentary mores and a condescending Tory MP played by George Baker. Annie's Bar, another fairly tame comedy featured a similarly likeable lead character, a newly elected Conservative parliamentarian. ${ }^{10}$

British political comedies have been routinely subjected to the question as to whether they accurately portray 'the inner workings' of government. Margaret Thatcher, for one, was said to thoroughly enjoy Yes (Prime) Minister for its realistic depiction of 'what goes on in the corridors of power'. ${ }^{11}$ Thatcher was notoriously sceptical of a civil service she suspected of being resistant to her zealous reform agenda. That this particular series dwelt on this tension may in part have been due to the fact that co-creator Anthony Jay was also an occasional speechwriter for the Conservative Prime Minister. Many others have praised the Yes Minister franchise for its 'unparalleled realism' (Cole, 2008), claiming that it is 'famously accurate in the spirit of the relationship between civil servant and politician'. ${ }^{12}$ The Thick of $I t$, likewise, has been examined for its supposed portrayal of reality, especially because of the allegedly close resemblance between the Tucker character and Alastair Campbell, the chief spin doctor for the larger part of the Blair government. ${ }^{13}$ One right-wing critic argues that most of the characters in The Thick of it 'are very thinly veiled from real life. 'Many of the plots are reworked versions of what we have endured on our news bulletins these last eight years' (Phibbs, 2005). Adding to the supposed realism of the political sitcoms is their perceived direct connection to real politics and politicians. The Yes Minister writers, for instance, took inspiration from the diaries of a former minister, and discussed plot lines with senior civil servants. By contrast the character of Alan B'Stard in The New Statesman was

10 In addition, the 1990s was the decade in which writer Guy Jenkin, co-creator of various comedies and political satire, made a number of single comedies for TV including Crossing the Floor, Mr. White Goes to Westminster and Lord of Misrule, and jointly produced Look at the State We're In (1995).

$11 \mathrm{http}: / /$ www.yes-minister.com/introduc.htm, last accessed April 22, 2010.

12 http://www.bbc.co.uk/comedy/yesminister/, last accessed April 22, 2010.

13 http://www.guardian.co.uk/tv-and-radio/2009/oct/17/peter-capaldi-malcolm-tucker-tv, last accessed April 22, 2010. 
adopted by the Sunday Telegraph for one of its weekly columns about actual events in Westminster. And it was something of an inevitability that Alastair Campbell, Michael Portillo (former Conservative MP and minister) and lan Hislop (editor of the satirical magazine Private Eye) would appear on different British television programmes to discuss the realism of In the Loop, the film version of The Thick of It.

\section{Thrillers}

Mostly British political television thrillers are stories of conspiracies, with identifiable collective actors undermining government and/or the democratic process for political or financial gain. Screen Online editor Marc Duguid identifies George Orwell's novel 1984 as the 'true ancestor' of the conspiracy genre in Britain. The novel was adapted into a television play as early as 1954, providing 'the template for a series of dramas imagining a dystopian Britain in which totalitarianism has overturned democracy' (Dugiud, no year). According to Duguid, the ensuing political thrillers of the 1970s (including The Guardians, The Donati Conspiracy and State of Emergency) portrayed authoritarian, far right or military regimes facing challenges from leftish rebel or paramilitary movements. In contrast Duguid suggests the thrillers of the 1980 s tell less Orwellian stories but rather focus on concrete ideological battles in which ruthless right-wing patriotism in government is contrasted with democratic forces on the left. Apart from portraying sinister state sponsored forces, particularly relating to the intelligence agencies, these thrillers also raised suspicion of covert foreign interference in British politics. More recently, in thrillers that are set in a wider setting of media, public office and economic interests, corporate power has been identified as the source of conspiracy be it the food industry in Natural Lies (1992), big oil in State of Play (2003) or global finance capital in The State Within (2006). Here there is an obvious parallel with the Hollywood remake of The Manchurian Candidate, arguably the most powerful screen conspiracy thriller, the original of which appeared shortly and somewhat prophetically before the assassination of John $F$ Kennedy.

The most famous British political TV-thriller, House of Cards, is the only one that does not contain a standard conspiracy narrative, but instead presents the story of coldblooded and suave Tory Chief Whip Francis Urquhart on his Machiavellian route to the premiership. Three four-episode seasons $(1990,1993,1995)$ show Urquhart eliminating his opponents through blackmailing, leaking compromising details to the press and literally killing the people in his way.. In the final season, Urquhart's many schemes unravel and he is himself removed through assassination. However his assailants are not driven by righteousness as the more usual narrative would have it, but are his complicit wife and bodyguard determined to protect their own interests. More generally the classic 
hero with high moral standards who is on a quest for justice and prevails in the face of adversity is difficult to find within the British political TV-thriller. ${ }^{14}$ The British characters taking on the conspiracies they uncover are more commonly flawed, not necessarily good looking, congenial or morally correct. The journalist played by John Simm in State of Play (2003), for instance, who discovers the depth of corporate influence in the UK government, is not conventionally handsome, drinks too much and sleeps with a friend's wife. Nevertheless he succeeds in the end. Duguid's conclusion about The Guardians (1971) is arguably applicable to later political thrillers: "The viewer is presented with a complex ethical universe in which oppressors and resistance alike are plagued by conscience and self-doubt." ${ }^{15}$ In addition, while the main characters may pursue a decent course of action, their victories are often framed as temporary or artificial. Typical is the final scene in A Very British Coup (1988): although Prime Minister Harry Perkins has managed to call elections against the wishes of his opponents, the series ends with the ominous shadow of a helicopter descending on a polling station as symbolic of the vanquishing of democracy. The typical narrative of the British political TV-thriller appears inhabited by ordinary and flawed people partially succeeding in doing the decent thing. But it would seem the putative happy end is only the beginning of new trouble.

Like the comedies, the thrillers are similarly intricately tied to real life politics and politicians. The 1970s and 1980s outputs featuring state surveillance are also informed by the growing influence of new technology. Furthermore many were framed as implicitly referring to the situation in Northern Ireland, an ongoing conflict which provided the rationale for the growing power of the so-called secret state. Broadcasters, especially the BBC, were fearful of becoming mired in this controversy and they, like other media producers, were often prone to (self) censorship (cf. Curtis, 1983). Further to this the inclusion of paramilitary attacks in the early thrillers was connected to the left-wing terrorism in Germany and Italy in the 1970ies (Duguid, no year). Natural Lies (1992) was inspired by the BSE food crisis, whereas The State Within (2006) was loosely based on the strained relations between the Bush and Blair governments in the prelude to the Iraq invasion. More direct links are ubiquitous: A Very British Coup (1988) was scripted by Alan Plater from a novel authored by left wing newspaper editor and later Labour MP Chris Mullin and the subsequent TV production was created with advice from various journalists including Alastair Campbell of the Daily Mirror (Birchell, no year). The House of Cards trilogy was based on a novel written by Michael Dobbs, a former Conservative chief of staff, and its release in 1990 coincided with the Thatcher leadership crisis and her eventual

\footnotetext{
${ }^{14}$ A possible exception is The State Within where Jason Isaacs' character is depicted as a wholly admirable senior diplomat of the utmost integrity. It is a portrayal more familiar to American productions dealing with similar politically related subject matter. The series was a co-production of BBC-UK and BBC-US, and featured many prominent US actors.

${ }^{15}$ http://www.screenonline.org.uk/tv/id/539954/index.html, last accessed May 8, 2010.
} 
downfall. The timing could not have been better with life imitating art with the series feeding back into British politics and Urquhart's favorite comment "You might very well think that, I couldn't possibly comment" being quoted in the House of Commons. ${ }^{16}$ The Dobbs and Mullin/Plater productions are also the most memorable political conspiracy thrillers to have been broadcast and though made within close proximity to one another, they nevertheless were quite distinctive reflecting their ideological perspectives of their respective writers. Urquhart was the classic 'bad apple in the barrel', a familiar Conservative construct to explain a politicians' failings. By contrast Perkins and his colleagues was the victim of a huge plot which included a traitor in his own Cabinet.

\section{Drama}

Political drama on UK television focuses on the human emotions involved in politics, and the social and psychological relations between the main characters. That gives most of these productions a specific 'soapish' flavor with the difference coming in the particular political setting as well as the sources of the dramatic developments. A particular and recurring theme here is the tensions that everyday political, party and media pressures create, especially for left wing activists and idealism. This subject had previously been explored in the earliest single play, notably Vote, Vote for Nigel Barton. Now it featured in a full fledged series, Bill Brand (1976), which contemplated the problem of maintaining radical convictions and trying to reconcile these in the face of everyday political wheeling and dealing. 11 episodes told the story of the conflicting pressures arising from idealism, family demands, local ties, party leaders and media pressure. Love and Reason (1993) tells a similar story but connects it to the rise of a relatively young 'radical' feminist politician who is forced to reconsider her ideals and negotiate fraught relationships with both her local party executive and a fellow MP with whom she becomes involved. Our Friends in the North (1997) is similarly predicated on the theme of left-wing politics and the inevitability of compromise. The series provided a compelling dramatic arc covering three decades and one which had narratives taking in the decline of the family, community, the North, industry, collective action as well as the ageing process, personal and political disillusionment, adultery, mental illness, alienation and a host of other themes. David Hare's play Absence of War, adapted for television, took up the theme of an ostensibly principled Labour leader making compromises in a desperate, ill fated bid for power in a play which closely mirrored the events surrounding the party's traumatic 1992 defeat. The most recent exploration of left-wing idealism confronting the supposed realities of gaining and taking office, the Project (2002), was a two part production which focused on the compromises two youthful eco-activists make on

\footnotetext{
${ }^{16}$ http://news.bbc.co.uk/2/hi/entertainment/6346897.stm, last accessed May 9, 2010.
} 
joining the Blair led Labour party both before as well as after taking office. Based on exhaustive research, the drama featured thinly veiled references to many significant actors and events.

Other drama series that tell less overtly political stories commonly focus on personal narratives of support and betrayal, success and failure; in these cases the parliamentary stage is more of a backdrop for compelling emotions and conflicts rather than the driver of plots and developments. First Among Equals (1986) based on Jeffrey Archer's book of the same name is an example of this approach, relating the story of four protagonists who vie for political prominence and ultimately the British Premiership. In The Politician's Wife (1995) the central character triumphs over adversity despite having been humiliated by her philandering husband, an ambitious and prominent Tory MP. Having dutifully stood by him she finds renewed dignity by helping to undermine his promising career before successfully emerging as a candidate in her own right. Party Animals, an eight episode series broadcast in 2007, tells a similar story of rivalry and adversity with further poignancy added by the early death of a major character.

Given that the key generic developments in television drama revolve around the relationships that develop between characters with multifaceted personalities, with all their strengths, flaws and inner turmoil, the emergence of individual heroes and villains in these series is a rarity although these behaviours may be witnessed. Many story lines deal with friendships and fall outs that result from conflicting understandings as to the best way to realize one's political ideals. The opportunism displayed by those wanting to enhance their goals, career or personal life is thus the most malign behaviour and this is something commonly shared by other characters. In Party Animals the drama is based around a major conflict between two twenty-something aides of a female MP: the naïve, idealist Danny who has a crush on his egocentric, ambitious colleague Kirsty. Danny is usually portrayed as occupying morally high ground although he too is fallible, notably when he causes his employer major difficulties arising from his leaving a sensitive document in the toilets of Westminster bar. A notable exception to the general tendency of featuring non-heroes in political TV is The Amazing Mrs. Pritchard (2006). This series portrays supermarket manager Ros Pritchard who, fed up with complacent politicians, decides to run for office and becomes the head of a new momvement and ultimately Prime Minister. Her no-nonsense, honest style is promoted both in and by the series as a more typically female approach which provides a much needed challenenge to the 'old' politics (see for more in-depth analysis of this series, Corner and Richardson, 2007).

Political drama is often an articulation of real life experience. Vote, Vote for Nigel Barton (1965) was based on its writer Dennis Potter's own personally unedifying experience as a Labour candidate. Similarly Jeffrey Archer's First Among Equals (1986) referenced aspects of his own rise and fall as a Conservative politician. Our Friends of the North (1997) contained an episode set against the 1980s 
miner's strike as well as numerous events relating to Newcastle politics. The Project (2002) carried on this chronology by concentrating on offering an account of the rise of New Labour. For its part Party Animals (2007) was positively reviewed by a critic for the The Independent in terms of its realistic representation of 'the engine rooms of the Westminster village'. ${ }^{17}$ Similarly The Line of Beauty struck a chord with pro-Labour commentators who used it to invoke memories of life under Margaret Thatcher, a figure who herself features in a series exploring social climbing and Conservative party mores during the 1980s. More than the other two genres, the suggestion of realism in this kind of drama comes from the seemingly emotional credibility of the story lines together with the the relationships and the inner conflicts of the characters. Here a more general aspect of soap stories is relevant and this is what Ang refers to as the ability to conjure up 'a tragic structure of feeling' in which personal problems are ubiquitous, repetitive and the prospect of solutions always illusionary or, at best, temporary (Ang, 1985, p. 46). Given this context it seems little surpise that the most popular kind of tension to narrate in thish melodramatic imagination is that of the almost inevitably compromise between left-wing (invariably Labour) idealism and adopting a more reformist position to change the status quo.

\section{Discussion}

Across the genres and through time there are, apart from the many differences examined above, some striking similarities in British TV-fiction about politics. In terms of characters, it is rare to encounter a classic or Hollywood type of hero who is successful, maintains the moral high ground and is physically attractive. More likely, whether one watches comedies, thrillers or drama, the main characters are mostly plain men of uncertain, around 40 or over, age, somewhat grumpy, somewhat clumsy and hardly ever in full control of their situation. The exceptions are interesting for their further evidence of the assumed underlying normality of politics. Two male characters that were shown as fully in command are the malevolent agents in their narrative: Francis Urquhart of The House of Cards thriller, and Alan B'stard of the comedy The New Statesman. The few leading characters that did manage to conquer their adversaries and portrayed relatively decent and successful political performers in a quest for their political ideals, were women: Jean Price in No Job for a Lady, Flora Matlock in The Politician's Wife, and Mrs. Pritchard in the series of the same name. The not so implicit message through time and across genres thus seems to be that good, strong and handsome men are a rare species in politics, and that the average politician is not deeply principled and struggling above his level of control.

\footnotetext{
${ }^{17} \mathrm{http} / / /$ www.independent.co.uk/news/uk/politics/new-bbc-drama-explores-the-wild-side-of-life-inwestminsters-political-village-432896.html, last accessed May 21, 2010.
} 
The dominant themes across time and genre link closely to these types of main characters: in most thrillers they are overwhelmed by sinister outside forces or inside political machinations; in comedies, especially in Yes (Prime) Minister and The Thick of It, they need a civil servant or a spin doctor to help them understand and play according to the inside rules; and in drama it is the recognition of how the political machinery works that frustrates them or makes them compromise their ideals. If anything the neo-liberal order has further emphasized this by focusing on the activities and manipulations of unelected aides and advisers; furthermore there has been a noticeable trend in TV drama which, although ostensibly dealing with political material, has tended to avoid the formal structures because it prefers to locate and concentrate on the power of extraparliamentary actors, notably in the corporate world. The narrative of the political machinery that exerts its inescapable corruption over all individual politicians thus runs strongly through the three genres across the whole time period. Vote Vote for Nigel Barton, the 1965 single play about the unsuccessful parliamentary career of a Labour idealist is, in that respect, very similar to 2002 miniseries The Project about the frustrations of young New Labour supporters, notwithstanding the almost 40 year time lapse between their release. Nevertheless, the most chance of a story in which the characters are able to realize some of their ideals is drama, yet, its particular soapy way of telling the story prevents that a sense of lasting success and closure is attached.

A further similarity across time and genre is that most series are firmly linked to real life politics: writers and advisers have often been part of Westminster themselves; real political figures regularly turn up in brief cameo appearances; some story lines relate to historical or topical political events, other storylines exploit current societal threats; some characters are based on real political figures. The range of articulations with real life politics is wide and persistent, and frames this kind of TV-fiction always in the context of the question whether it represents political reality in a veritable way. It is this particular aspect that produces its potential relevance for affecting people's political understandings, judgments and engagement. Perceived realism is one of the clearly identified mechanisms through which television effects have been seen to occur be it always mitigated by specific circumstances (e.g. Bussel, 2001). It is therefore tempting to draw self evident conclusions about the politically engaging qualities of British political TV fiction, especially when we contrast it with its US counterparts. With some exceptions that are mostly found in recent drama, the characters and stories in UK political television fiction present a rather gloomy understanding of how politics works and what individuals can achieve there. It is a marked distinction from most American political television and film fiction in which the outcome of the characters' struggles with conspiracy, bureaucracy, political and personal predicaments is most of the time positive, showing that one can prevail regardless of the width and depth of adversity. Obama's Yes, We Can radiates from these stories, whereas British TV-fiction, with some exceptions seems to say something that is closer to "no 
use trying", unless you are an evil schemer. To exaggerate the distinction somewhat, one could say that most American political TV fiction tells stories of hope, where as British political TV fiction tends to narrate stories of despair. Not for nothing is Harry Perkins' refrain 'don't let the bastards grind you down'. It should also be borne in mind that this is not a new staple of political fiction and is one that stretches back to those lodestars of their respective nations' work in this area: Mr Smith Goes to Washington (1939) and Fame is the Spur (1947).

On the basis of these differences, we could expect American series to inspire, whereas the British versions would tend to discourage, especially because of the repeatedly recurring theme that the political machinery trends to crush individual agency. In comedy that is usually the source of the laugh, in drama it is the source of tensions from which there is hardly an escape. While the obvious objection to such a conclusion is that actual audience interpretations are usually much more complicated and contradictory than such a one dimensional effects thesis suggests, there are other caveats as well. It is important to note that television fiction in itself is as much a product of political culture, as that it may affect it. The individual heroism present in much American political film and TV fictions, while typical for Hollywood narrative, is also obviously linked to the US presidential system of politics, in which individual officeholders hold relatively much power, whether it is the president himself or lower level public officials. In British politics, on the other hand, while narratively cast in the simple opposition between two rival parties ${ }^{18}$, it is the parliament that is key, with individual MPs always needing to negotiate, compromise or retreat. The same holds for another aspect of British political TV fiction: throughout the years it has offered a popular frame for journalists to make sense of politics in their reporting, and in some cases for politicians to make their comments more plausible. Yet, such frames have by and large been applied in a critical, even condescending manner (cf. Van Zoonen, 2003), and it is, again, tempting to conclude that this is the result of the dark undertones of much UK political TV-fiction. On the other hand, if we approach both fiction and journalism as linked to the particularities of British politics, the relation between the three of them becomes much more complex than one dimensional effect models allow for and would better be approached as interactional and iterative, than as one-directional and definitive: Westminster journalists recognize fictional representations as realistic and use it to retell their own stories that are rooted in perception of what goes on in Westminster that is as dark as that of fiction writers.

All these questions offer different venues for further research. The longitudinal and comparative character of this study meant that textual specificities could not be analysed in detail; thus the emergence of women as almost the only characters that were seen to take on a somewhat heroic role deserves further examinations. In addition, the ideological leanings of the various series

\footnotetext{
${ }^{18}$ Until the recent elections of 2010, which saw the rise of a third party and a coalition government, much to the surprise and turmoil of voters and representatives alike.
} 
discussed suggest a Labour, left-wing leaning of much drama that also requires a more in-depth treatment. In terms of production and reception of these series, the questions concern, first, the particular perceptions, motives and reflections of political fiction screen writers and producers, and second, the specific interpretations of politics by audiences that result from the stories analysed here. Obviously, all of these constitute a full agenda for further research.

\section{References}

Birchell, D. (no year). Very British Coup, A. Screen Online, http://www.screenonline.org.uk/tv/id/485767/index.html, accessed May 9, 2010.

Bussel, R. (2001). Television Exposure, Perceived Realism, and Exemplar Accessibility in the Social Judgment Process. Media Psychology, 3(1), p. 43-67.

Christensen, T. and Haas, P. (2005). Projecting politics: political messages in American films. Armonk, NY.: M.E.Sharpe.

Cole, T. (2008). Why I love ... Yes Minister. Radio Times, July 24, http://www.radiotimes.com/blogs/365-why-i-loveyes-minister/ , last accessed April 22, 2010.

Corner,J. and K. Richardson (2007). Political culture and television fiction: The Amazing Mrs.

Pritchard. European Journal of Cultural Studies, 11 (4), p. 387-403.

Curtis, L. (1983). Ireland, the propaganda war. The British media and the battle for hearts and minds. London: Pluto Press.

Duguid, M. (no year). Conspiracy drama. ScreenOnline, http://www.screenonline.org.uk/tv/id/524081/, last accessed May 8, 2010.

Fielding, S. (2008). A mirror for England? Cinematic representations of politicians and party politics, ca. 1944-64. Journal of British Studies, 47(1), 107-28

Gianos, P. (1998). Politics and politicians in American film. Westport, CT: Preager Publishers.

Giglio, E. (2005). Here's looking at you. Hollywood, film and politics. New York:Peter Lang.

Givskov, C. (2009) Genre on time. Fiction film framings of scandalous politics in Denmark since 2001. Northern Lights, 7(1), p. 153-172.

Harvie, C. (1991). The centre of things: political fiction in Britain from Disraeli to the present. London: Routledge.

Haas, E. (2005). Women, politics and film. P. 249 -277 in Christensen, T. and Haas, P. Projecting politics: political messages in American films. Armonk, NY: M.E.Sharpe.

Holbert, R. L. (2005). A typology for the study of entertainment television and politics. American Behavioral Scientist, 49, 436-453. 
Holbert, R. L., Pillion, O., Tschida, D. A., Armfield, G. G., Kinder, K., Cherry, K., \& Daulton, A. (2003). The West Wing as endorsement of the American presidency: Expanding the domain of priming in political communication. Journal of Communication, 53, 427-443.

Horton, J. and A. Baumeister (1996). Literature and the political imagination. London: Routledge. Krukones, M. (2003). Motion picture presidents of the 1930s. In Rollins, P.C. and J.E. O'Connor (eds). Hollywood's White House. The American Presidency in Film and History. Lexington: The University of Kentucky Press.

Neve, B. (1992). Film and politics in America: a social tradition. London: Routledge.

Parry-Giles, T. and S. Parry-Giles (2006). The Prime-Time Presidency. The West Wing and US nationalism. Urbana, III.: University of Chicago Press.

Phibbs, H. (2005). The Thick of It. Social Affairs Unit, November 23. http://www.socialaffairsunit.org.uk/blog/archives/000670.php, last accessed April 22, 2010.

Pompper, D. (2003). The West Wing. White House narratives that journalism cannot tell. In Rollins, P. and J. O'Connor (2003)(eds). The West Wing. The American presidency as television drama. Syracuse, NJ.: Syracuse University Press, p. 17-31.

Rollins, P. and J. O'Connor (2003)(eds). The West Wing. The American presidency as television drama. Syracuse, NJ.: Syracuse University Press.

Street, J. (2002). Cultures of cynicism: popular television drama and antipolitics. Paper presented at the ECPR joint sessions, Turin.

Tenenboim-Weinblatt, K. (2009). Where Is Jack Bauer When You Need Him? The Uses of Television Drama in Mediated Political Discourse. Political Communication, 26 (4).

Van Zoonen, L. (2003). After Dallas and Dynasty, we have ..... Democracy. Articulating Soap, Politics and Gender. In J. Corner and D. Pels (eds). Media and the restyling of politics. London: Sage, p. $99-117$.

Van Zoonen, L. (2005). Entertaining the citizen: when politics and popular culture converge. Boudler, CO: Rowman and Littlefield.

Van Zoonen, L. (2007). Audience reactions to Hollywood politics. Media, Culture and Society, 29(4), p.531-547. 
Appendix. British political TV-fiction, 1965-2009.

\begin{tabular}{|c|c|c|c|c|}
\hline Year & Title & $\begin{array}{l}\text { Episodes/ } \\
\text { seasons }\end{array}$ & Genre & Narrative \\
\hline 1965 & Vote Vote for Nigel Barton & 1 & Drama & Bureaucracy \\
\hline 1971 & The Guardians & 13 & Thriller & Conspiracy \\
\hline 1973 & The Donati Conspiracy & 3 & Thriller & Conspiracy \\
\hline 1974 & All Good Men & 1 & Drama & Melodrama \\
\hline 1975 & State of Emergency & 1 & Thriller & Conspiracy \\
\hline 1975 & The nearly man & 7 & Drama & Melodrama \\
\hline 1976 & Bill Brand & 11 & Drama & Melodrama \\
\hline 1980 & Yes Minister & $22(2)$ & Comedy & Bureaucracy \\
\hline 1986 & Yes Prime Minister & $16(2)$ & Comedy & Bureaucracy \\
\hline 1986 & First Among Equals & 10 & Drama & Melodrama \\
\hline 1987 & The New Statesmen & $28(4)$ & Comedy & Bureaucracy \\
\hline 1988 & A Very British Coup & 3 & Thriller & Conspiracy \\
\hline 1990 & No Job for a Lady & $18(3)$ & Comedy & Bureaucracy \\
\hline 1990 & The House of Cards Trilogy $[90,93,95]$ & $12(3)$ & Thriller & Conspiracy \\
\hline 1991 & GBH & 7 & Drama & Conspiracy/melodrama \\
\hline 1993 & The Vision Thing & 1 & Comedy & Melodrama \\
\hline 1993 & Love and Reason & 3 & Drama & Melodrama \\
\hline 1995 & The Absence of War & 1 & Drama & Bureaucracy \\
\hline 1995 & The Politician's Wife & 3 & Drama & Melodrama \\
\hline 1995 & Look at the state we're in & 6 & Comedy & Bureaucracy \\
\hline 1996 & Annie's Bar & 8 & Comedy & Bureaucracy \\
\hline 1996 & Lord of Misrule & 1 & Comedy & Melodrama \\
\hline 1996 & Crossing the Floor & 1 & Comedy & Bureaucracy \\
\hline 1997 & Mr. White Goes to Westminster & 1 & Comedy & Bureaucracy \\
\hline 1997 & Our Friends in the North & 9 & Drama & Melodrama \\
\hline 1998 & In the Red & 1 & Thriller & Conspiracy \\
\hline 2002 & The Project & 3 & Drama & Melodrama \\
\hline 2003 & My dad's the Prime Minister & $13(2)$ & Comedy & Bureaucracy \\
\hline 2003 & State of Play & 6 & Thriller & Conspiracy \\
\hline 2005 & The Thick of It & $17(3)$ & Comedy & Bureaucracy \\
\hline 2006 & The Line of Beauty & 3 & Drama & Melodrama \\
\hline 2006 & The State Within & 7 & Thriller & Conspiracy \\
\hline 2006 & The Amazing Ms Pritchard & 6 & Drama & Quest \\
\hline 2007 & Party animals & 8 & Drama & Melodrama \\
\hline
\end{tabular}

